\title{
It's financialization!
}

\section{Citation}

Freeman, Richard B. 2010. “It's Financialization!" International Labour Review 149 (2) (August 24): 163-183. doi:10.1111/j.1564-913x.2010.00082.x.

\section{Published Version}

doi:10.1111/j.1564-913X.2010.00082.x

\section{Permanent link}

http://nrs.harvard.edu/urn-3:HUL.InstRepos:34548957

\section{Terms of Use}

This article was downloaded from Harvard University's DASH repository, and is made available under the terms and conditions applicable to Open Access Policy Articles, as set forth at http:// nrs.harvard.edu/urn-3:HUL.InstRepos:dash.current.terms-of-use\#OAP

\section{Share Your Story}

The Harvard community has made this article openly available.

Please share how this access benefits you. Submit a story.

Accessibility 
It's financialization!

Richard B. FREEMAN*

* Harvard University and National Bureau of Economic Research, Centre for Economic Performance, London School of Economics and International Labour Organization, email: freeman@nber.org.

Responsibility for opinions expressed in signed articles rests solely with their authors and publication does not constitute an endorsement by the ILO.

Abstract. Wall Street's 2007-09 implosion and the ensuing global recession highlight the crucial relationship between finance and the economy. Governments, international agencies and experts had failed to detect rising risk levels in the deregulated financial sector. The author outlines the resulting huge cost in lost jobs and likely reductions in public goods and growth, as economies restabilize budgets after paying for massive bailouts and stimulus packages. Specifically, he assesses the role of monetary incentives for rent-seeking in the decisions that led to the crisis. Finally, he makes the case for radical reform of the institutions linking finance and the real economy. 
In December 2009, the largest trucking firm in the United States, YRC, with over 30,000 truck drivers on its payroll was close to bankruptcy. The firm was financially stressed not so much because its revenues were falling in the recession but because it owed US $\$ 1.6$ billion in loans and bonds for acquisitions it had made in 2003 and 2005. ${ }^{1}$ To survive, YRC had to convince bondholders to swap bonds for equity.

Ten or twenty years earlier, bondholders would readily have made the exchange, since their bonds would essentially have proved worthless if the YRC had gone bankrupt. But in the 2000s era of financialization, Wall Street firms had issued credit default swaps (CDSs) against YRC bonds. ${ }^{2}$ Investors with CDSs who bought bonds and voted against restructuring would make more from the CDSs than they would lose from the bonds. Goldman Sachs developed a market in YRC bonds and CDSs, soliciting bonds for clients who would benefit from a failed exchange and bankruptcy. ${ }^{3}$ In early December 2009, the percentage of creditors who agreed to the exchange dropped from 75 to 57 per cent, and the value of YRC's notes due the following April fell to 59.75 cents on the dollar. YRC extended the deadline for the debt exchange and lowered the minimum participation rate of bonds tendered for the

1 It acquired Roadway Corp in 2003 for US\$1.07 billion and USF Corp in 2005 for US\$1.37 billion.

2 Credit-default swaps are financial instruments based on bonds and loans that are used to hedge against losses or to speculate on a company's ability to repay debt. They pay the buyer face value in exchange for the underlying securities or the cash equivalent should a borrower fail to adhere to its debt agreements.

3 The Goldman Sachs public relations office stated that "Goldman does not have a position in the company, nor are we making markets in the company's bonds or credit-default swaps", while Bloomberg news reported them sending emails to clients about those markets. See http://www.bloomberg.com/apps/news?pid=20601087\&sid=apCmuH.AP.VA, Pierre Paulden and Shannon D. Harrington" Hoffa Says Goldman Sachs Driving YRC Into Bankruptcy (Update1), Bloomberg news, Dec 17, 2009 
restructuring from 95 to 80 per cent, but the firm still seemed doomed - a real-economy victim of financialization. $^{4}$

Fast-forward six months. To the surprise of Wall Street and the business press, YRC escaped bankruptcy and remained in business. Goldman Sachs presumably decided that the potential displacement of thousands of truck drivers around Christmas time was not worth the profits it could earn. It changed direction and induced bondholders to accept the restructuring. Others on Wall Street also agreed to swap bonds for equity. The bankers' change of heart was not sparked by an outpouring of moral sentiment at Christmas time. The Teamsters Union, which represented YRC's truck drivers, had begun to raise a public stink about the impact of the CDSs on jobs. Thousands of truck drivers might have descended on Wall Street and Park Avenue and highlighted the divide between finance and Main Street at a time when the public was furious at the bankers and when the United States Congress and Administration were considering ways of reforming finance.

The YRC-Goldman-Teamsters case highlights the potential for a large, unregulated financial sector with Gordon Gekko-style ${ }^{5}$ ethics and little sense of fiduciary responsibility to harm the real economy, and the corresponding need for institutions with countervailing power to protect firms and workers from decisions based solely on financial considerations, including bets against the survival or success of a firm. It offers a springboard for analysing the relation between finance and the real economy in the light of the 2007-09 implosion of Wall Street and the ensuing global recession.

This article is in four sections. The first section describes the failure of governments, international agencies, financial experts and economists to keep their eyes on the ball of

4 See Paulden and Detrixhe (2010); also http://www.teamster.org/archive/2009 for 13 headline news reports and six press releases on YRC, all dated Dec. 2009 [accessed 14 May 2010].

5 Gordon Gekko was the chief protagonist of the 1987 film Wall Street, directed by Oliver Stone. The character was loosely based on Ivan Boesky, the arbitrageur who coined the phrase "greed is good". A sequel, Wall Street: Money never sleeps, was presented at the Cannes Film Festival in May 2010. 
finance as they proceeded to deregulate the sector prior to the 2007-09 implosion of Wall Street. The second section documents the huge costs to the real economy of the financeinduced "Great Recession", in terms of lost employment and likely reductions in public goods and economic growth as countries re-stabilize their fiscal budgets following costly bailouts and stimulus packages. The third section assesses the role of monetary incentives for rentseeking in motivating the decisions that led to the financial disaster. The final section argues that the costs to society of uncontrolled finance evident in the 2008-09 crisis were sufficiently high to justify radical reforms of the institutions linking finance and the real economy.

Financial deregulation in some countries, notably the United States, has also had a destabilizing effect on countries that otherwise had a prudent financial management. This is because international capital flows respond to reflect the "manics" and "panics" of financial markets as well as to economic fundamentals. Developing countries have been especially vulnerable to this, as the paper by Jayati Ghosh in this volume shows.

Financial economics teaches us that the job of finance is to spread the effects of risks among large numbers of people, so that no one bears intolerable levels of risk (Shiller, 2003, p. 1$)^{6}$ and to direct capital to its most productive uses. In the deregulated capital market of the 2000s, finance did the opposite. It increased risk through leveraging, speculation, and caveat emptor rent-seeking. It did so with practices that were chicanery at best and crime at worst. Restoring finance to its role as a productive force in the economy will require new institutions and modes of compensation, as part of a general overhaul of the relation between finance and the real economy. Since labour and normal citizens bear so much of the cost of the failure of finance to do its job, it is incumbent upon those who represent labour (be they unions, ministries of labour and social protection, elected officials, or employers who care about their

6 Shiller goes on to say that: "finance ... has made stunning progress in the second half of the twentieth century, both in theory and in practice (p. 11) ... risk does not disappear but its effects virtually disappear as the risks to the individual business are blended into large international portfolios where they are diversified away to almost nothing among the ultimate bearers of the risk, the international investors (2003, p. 3). 
workers) to seek such reforms. The lesson from the past two decades is that the bankers and their allies in politics and academe will not make the necessary reforms by themselves.

The laissez-faire economic experiment

Beginning in the 1980s, the United States and many other countries ran a giant experiment in laissez-faire capitalism. Trusting that the efficient market hypothesis reflected how financial markets worked and that the Washington Consensus view of the global economy offered the correct vision of international trade and finance, governments around the world deregulated capital markets. To protect workers from shifts in market conditions, they sought to increase labour market flexibility by deregulating labour markets as well.

The programme to deregulate finance was based on theory and ideology. Evidence that an unbridled global capital market would improve economic outcomes was non-existent. Comparing the performance of countries with differing degrees of attachment to the global capital market over time, the International Monetary Fund (IMF) research economists, Kose, Prasad, Rogoff and Wei (2006), found little evidence that the financial liberalization expounded by the IMF as the best policy for the world in fact improved performance. They concluded that: "further research is clearly needed in a number of areas before one can derive strong policy conclusions. ... some of the more extreme polemic claims made about the effects of financial globalization on developing countries, both pro and con, are far less easy to substantiate than either side generally cares to admit" (Kose et al., 2006, p. 53). Similarly, the analysis by Prasad, Rajan and Subramanian of international capital flows led them to conclude that "greater caution toward certain forms of foreign capital inflows might be warranted" (2007, p. 32). The words - further research needed, less easy to substantiate, greater caution ... warranted - are bureaucratic ways of saying that there was no empirical support for the claim that economies which joined the global financial system under thenprevailing rules did better than those which did not. By 2009, after the collapse of Wall Street, 
the head of the IMF said the agency had no objection to capital controls - which it had strongly opposed in the 1990 s. $^{7}$

Historical experience tells a story about the impact of the deregulation of finance at variance with the vision of perfect markets operating with minimal friction that motivated the laissez-faire experiment. In the United States, deregulation of savings and loans produced the 1980s savings and loan crisis, the 1996 collapse of Long-term Capital Management showed how fragile the new financial tools were for the task of reducing risk, while the dot.com boom and bust showed that bubbles still affected Wall Street, as they had in past decades. Looking outside the United States, the 1992 financial crisis in Sweden; the late 1980s Japanese assetprice bubble that produced Japan's lost decade; the 1997 Asian financial crises; and the 124 bank crises enumerated by the IMF for the period 1970-2007 (Laeven and Valencia, 2008) demonstrate that finance remained the squeaky wheel of capitalism in the latter part of the 20 th century and at the onset of the 21 st century, as it had in earlier periods.

History notwithstanding, most economic leaders in the United States and other advanced countries and in international financial agencies endorsed the laissez-faire experiment, seemingly convinced by theory, ideology or the desire of the leaders of financial institutions to profit from less regulation that "this time would be different" ${ }^{8}$ Indicative of the prevailing attitude, Alan Greenspan, the Chair of the United States Federal Reserve, extolled CDSs as providing ideal insurance for the new financial products: "As the market for credit default swaps expands and deepens, the collective knowledge held by market participants is exactly reflected in the prices of these derivative instruments ... [which] embody all relevant market prices of the financial instruments issued by potential borrowers." ${ }^{9}$ When the head of

$7 \mathrm{http}: / /$ www.brettonwoodsproject.org/art-566106.

8 This paraphrases the title of the book by Carmen Reinhart and Ken Rogoff: This time is different: Eight centuries of financial folly (2009), which documents centuries of finance-induced crisis throughout the world.

9 Alan Greenspan, Chairman, Fed. Reserve Bd., Remarks before the Council on Foreign Relations: International Financial Risk Management (19 Nov. 2002), available at 
the United States' Commodity Futures Trading Commission, Brooksley Born, sought public debate and evidence on the growing use of derivatives in 1998, Greenspan joined Secretary of the Treasury Rubin, Securities \& Exchange Commission Commissioner Arthur Levitt, and Deputy-Secretary of the Treasury Lawrence Summers to squelch her for "cast[ing] the shadow of regulatory uncertainty over an otherwise thriving market." ${ }^{10}$ Congress enacted the Commodity Futures Modernization Act, which pre-empted derivatives from oversight under state gaming laws and excluded certain swaps from being considered securities under SEC rules. ${ }^{11}$ Apparently, the financial-political complex could not imagine that CDSs or other financial instruments might endanger the real economy.

Whatever its effects on the rest of the economy, the deregulation of finance spurred growth, profits, and high earnings for the financiers. OECD data for France, Germany, Japan, the United States and the United Kingdom show that finance (financial intermediation, real estate, renting, and business activities) increased its share of GDP in the 1990s and 2000s. The ILO's analysis of national income accounts data in 17 countries shows that the financial sector's share of profits increased from 32 per cent in 1990 to over 40 per cent in 2005, while the ratio of financial-sector profits to the wages and salaries of all private-sector workers rose from 25 to 38 per cent (IILS, 2009, fig. 2.1, p. 48). In the United States, the ratio of financial assets divided by GDP jumped massively, the proportion of domestic corporate profits going to finance zoomed from 10-15 per cent during the 30 years following the Second World War to $35-40$ per cent in the 1980 s and 1990 s. Compensation per full-time equivalent employee in the security and commodity brokering industry increased from 146 per cent above the

http://www.federalreserve.gov/BoardDocs/Speeches/2002/20021119/default.htm [accessed 20 May 2010].

10 Lawrence H. Summers, Deputy Secretary, United States Department of the Treasury, Testimony before the Senate Committee on Agriculture, Nutrition, and Forestry on the CFTC Concept Release (30 July 1998), available at http://treasury.gov/press/releases/rr2616.htm [accessed 20 May 2010].

11 Pub. L. No. 106-554, 114 Stat. 2763, 2763A-411 (2000). 
national average in 1990 to 290 per cent above average in 2007, while total compensation for security and commodity brokers went from 31 to 93 per cent of total compensation for federal civilian employees. ${ }^{12}$ Much of the increase in incomes went to those in the highest positions, as inequality increased more in finance than in other sectors. In 2006, Wall Street paid out US\$62 billion in bonuses (Zuckerman, 2008). Some heads of hedge funds earned US\$1 billion or more a year (Anderson and Creswell, 2007). ${ }^{13}$

In turn, the huge earnings in finance attracted many of the world's best and brightest university graduates to jobs in finance, shifting human capital from the real economy to financial rent-seeking. Moreover, such earnings boosted the esteem in which these financial executives were held by politicians and the general public. We all listen to someone who makes millions for a firm earning billions in profits, almost regardless of what he/she says. Such people must know something unique about the economy to have done so well. "When the money comes rolling in, you don't ask how. Think of all the people guaranteed a good time now. When the money keeps rolling out you don't keep books. You can tell you've done well by the happy grateful looks. Accountants only slow things down, figures get in the way." 14

The experiment with laissez-faire finance came to a sudden end in September 2008, when Lehman Brothers went bankrupt. The Wall Street Journal referred to the subsequent implosion of banking and finance as "The Weekend Wall Street Died" (Craig, 2008). Credit froze. Banks had "toxic assets" of questionable value on their books, which made other banks

12 See Bureau of Economic Analysis, Table 6.2C. Compensation of Employees by Industry, $\mathrm{http} / / / \mathrm{www} \cdot$ bea.gov/national/nipaweb/SelectTable.asp?Selected=N (choose table 6.2c, then choose 1990 for the "First Year" and "Last Year," then click "Update") (last visited Feb. 27, 2010); Bureau of Economic Analysis, Table 6.2D. Compensation of Employees by Industry, http://www.bea.gov/national/nipaweb/SelectTable.asp?Selected=N (choose table 6.2d, then choose 2007 for the "First Year" and "Last Year," then click "Update") (last visited Feb. 27, 2010).

13 James Simons, Kenneth C. Griffin and Edward S. Lampert were listed as making over US\$1billion, with George Soros falling to a little below the billion dollar mark.

$14 \mathrm{http} / / /$ www.thebroadwaymusicals.com/lyrics/evita/andthemoneykeptrollingin.htm. 
unwilling to deal with them. At the same time, banks were uncertain of their own assets. They had off-the-books subsidiaries of unknown value and debt. American International Group, the large insurance firm which had paid US\$1.6 billion in fines for misreporting its books between 2000 and 2005 but was still viewed as one of the great financial institutions in the world, was about to crash. The CDSs and complex derivatives that Greenspan had extolled and the Clinton Administration's financial experts had protected from governmental investigation and possible regulation turned Wall Street into a house of cards.

With little information about the shadow banking system and derivatives that had grown massively during the period of benign neglect of finance, the United States' top economic policy-makers panicked. The head of the Federal Reserve, Ben Bernanke, and the Secretary of the Department of the Treasury, Henry Paulson, told Congress that the country had to bail out the banks immediately or face complete economic collapse - the end of capitalism, as it was. Faced with such a dire prospect, in October 2008 Congress created the Troubled Asset Relief Program (TARP) which gave the Department of Treasury extraordinary authority to purchase or insure up to US\$700 billion of troubled assets from the banking sector. The Federal Reserve used its powers to provide credit and low interest loans to the banks, so that they could stabilize their finances at the public's expense. Most banks used the government cash and guarantees to re-capitalize themselves and to pay the largest salaries and bonuses they could manage, in the name of "retaining talent". They did not make the new loans that would have funded investment or helped mortgagees refinance their homes and spur economic recovery.

The bailout of the banking sector ended the financial panic, ${ }^{15}$ but did not prevent the implosion from infecting the real economy. Real gross domestic output in the United States decreased at an annual rate of 5.4 per cent in the fourth quarter of 2008 and by 6.4 per cent in

15 In its 2009 year-end report the Congressional Oversight Panel concluded that TARP helped stabilize financial markets and restore the flow of credit, but warned that the banking sector was still on shaky ground. 
the first quarter of 2009 , versus activity in the year-ago periods. ${ }^{16}$ Other countries also registered substantial falls in GDP (Walker, 2009). In response, the incoming Obama Administration pushed the American Recovery and Reinvestment Act through Congress, in order to provide a Keynesian stimulus to the economy (Ohanian, 2009). Other governments also ran sizeable fiscal deficits.

A year after the collapse of Lehman Brothers and the putative death of Wall Street, the banking system was back, more concentrated than it was before the financial disaster. In September 2009, five Wall Street investment banks held 37 per cent of the sector's assets, while ten global banks held a sizeable proportion of world banking assets; this made them all "too big to fail". ${ }^{17}$ Early in 2010, major banks reported large profits, which encouraged the bankers again to pay themselves huge bonuses. Leading hedge-fund managers, speculating that the Government would indeed bail out the banks, reported the highest earnings in history. At the same time, financial experts and economists, including the IMF, worried that reduced government support for the banks or reduced deficit spending would precipitate another, possibly worse, bank collapse and double-dip economic recession. ${ }^{18}$ At the time of writing, the danger appears to lie in the huge public-sector deficits and rising debt in several European

16 United States GDP Growth Rate, available at: http://www.tradingeconomics.com/Economics/GDP-Growth.aspx?Symbol=USD [accessed 17 Mar. 2010].

17 For the United States, as of 31 Dec. 2009, the five largest bank holding companies in terms of total assets had US\$8.207 trillion in assets, as reported by the Federal Deposit Insurance Corporation on http://www.ffiec.gov/nicpubweb/nicweb/Top50Form.aspx. The Federal Reserve's flow of accounts file shows all bank holding companies having US\$27.21 trillion in assets, as of the last quarter of 2009; this gives the five largest 30 per cent of bank holding assets. See http://www.federalreserve.gov/releases/z1/Current/z1r-4.pdf, table L112, p. 7411 Mar. 2010. The Congressional Oversight Panel Report shows a market share of about 37 per cent for the four banks with the most deposits at table 12 (ibid. at p. 46); compare Whitehouse (2009) at p. A2, reporting that the world's ten largest banks have 70 per cent of global banking assets, with Bankers Almanac (2010), showing the world's ten largest banks with less than half of global banking assets.

18 For the IMF view, see http://www.marketwatch.com/story/banking-crisis-not-over-yet-imfwarns-2010-04-20. For fears of a double-dip recession, see Harrison (2009). 
Union countries, which spurred the IMF and the EU to seek to bail out Greece, and could produce sovereign debt default and another financial meltdown.

Even if international financial institutions and advanced-country governments are able to maintain stability in finance, the real economy is still fragile in those countries, with labour markets showing little sign of recovery (Baily and Schwartz, 2009).

Labour market flexibility to the rescue?

In the 1990s and 2000s, much economic policy in advanced industrialized countries focused on the labour market. Inspired by the OECD's Jobs Study and related analysis that blamed unemployment and sluggish growth in advanced Europe on labour market inflexibility, policy reforms sought ways of reducing welfare state benefits and limiting the impact of labour institutions on outcomes. The notion was that this would allow the labour market to adjust better to economic change and would spur greater efficiency. If labour markets could be as flexible as capital markets, all would be well in the world.

Like the vision of perfectly functioning unregulated capital markets, this perspective was based more on theory or ideology than on facts. The evidence that deregulating labour markets would improve outcomes was weak and questionable, as researchers critical of the Jobs Study showed and as the OECD has periodically recognized in its research (see Freeman (2007) and (2005)). But the notion that the labour market was the Achilles Heel of capitalism had considerable appeal for many advocates of the laissez-faire experiment. Labour institutions are more transparent and comprehensible than financial institutions. That the United States (with arguably the most market-driven and least institutionally influenced labour market among those of the major countries) had higher employment rates and faster productivity growth than most advanced European countries was a telling argument for seeking greater flexibility. 
The rapid rise in unemployment in the United States and most other advanced countries in 2008-09 shook up conventional thinking about policies toward labour. Assessing the effect of the global recession, the OECD concluded that the flexibility and structural reform policies it had recommended to member countries had done little to improve the ability of labour markets to respond to crisis:

There does not appear to be any strong reason to expect that recent structural reforms mean that OECD labour markets are now substantially less sensitive to severe economic downturns than was the case in the past. ... the "great moderation" (in economic fluctuations) apparently cannot be attributed to greater resilience due to the types of structural reforms that have received a lot of attention from labour market analysts and policy makers (p. 39)... there do not appear to be any clear grounds for concluding that workers, generally, are either better or worse prepared to weather a period of weak labour markets than was the case for the past several recessions (OECD, 2009, p. 40).

The OECD's phrases, like those of the IMF quoted earlier, are bureaucratic and cautious (... does not appear to be any strong reason ... apparently cannot be attributed ... do not appear to be any clear grounds) but the message is clear. Twenty or so years of flexibility reforms have accomplished essentially nothing towards insulating workers from the economic disaster wrought by laissez-faire capital markets. Analysing the adjustment of employment to output in manufacturing across OECD countries, the 2009 Employment Outlook reported that, despite the general trend of greater flexibility in hiring and firing due to weakened employment protection legislation and the increased use of temporary labour, the speed of adjustment of labour demand to changes in output was essentially unchanged (p. 91). In fact, faced with a real economic crisis, the OECD recommended that countries strengthen income support systems, extend unemployment insurance benefits, etc., for the duration of the recession - the opposite of its flexibility agenda. The OECD now believed that the danger was 
that lay-offs in a recession would break the link between workers and the job market and produce long-term unemployment. It hypothesized that the market-oriented policies it favoured had increased the vulnerability of employment to the great recession (possible, but difficult to establish) but reduced the persistence of unemployment (possible, but impossible to establish until employment recovers).

In sum, the laissez-faire experiment failed on two counts. Deregulation of finance produced greater instability in capital markets, with no compensating boost for growth of output, profits, or earnings save in the finance sector itself. When finance collapsed, efforts to increase labour flexibility did little to insulate workers and the real economy from the costs of financial mismanagement - costs that are, by any measure, massive.

Costs to the real economy

According to the IMF, recessions associated with financial crises last on average 18 months longer than other recessions and take almost three years to recover pre-recession output levels. Globally synchronized recessions are also longer and deeper than others. ${ }^{19}$ Given the increased lag between recovery of GDP and employment growth in the 1990s and 2000s, the ILO estimated that jobs would not recover in the advanced countries until 2015, assuming that all went well. In the United States, employment fell by 8 million from January 2007 to October 2009 , according to the Council of Economic Advisors (http://www.gpoaccess.gov/eop/tables10.html, table B36). The employment-population ratio dropped from 63 to 58.5 per cent. ${ }^{20}$ Unemployment in spring 2010 hovered around 10 per cent (Bureau of Labor Statistics, 2010), higher than the rate in the European Union (ILO, 2009).

19 See chapter 3 of the IMF's World Economic Outlook 2009, which studied 120 recessions and recoveries across advanced economies since 1960 (IMF, 2009).

20 See Bureau of Labor Statistics, Labor Force Statistics from the Current Population Survey, http://data.bls.gov/PDQ/servlet/SurveyOutputServlet? data_tool=latest_numbers\&series_id=LNS12300000 (change output options to "from 2000 to 2010" and click "go") (accessed 25 Feb. 2010). 
Millions of workers were on involuntary short-term and millions more were too discouraged by lack of jobs to seek work. The Bureau of Labor Statistics' most inclusive definition of labour under-utilization was 17.5 per cent of the work force in March 2010. ${ }^{21}$ Advanced Europe, Canada and Japan also suffered major job losses and high rates of unemployment that will last for a long time. ${ }^{22}$ Spain, with its larger number of temporary contracts, experienced the greatest increase in unemployment, since firms can fire workers quickly. Some countries "hid" their joblessness by paying firms to keep workers on board: Germany and Sweden in Europe, and the Republic of Korea. For the United States, only an economic miracle could restore full employment by 2015 . During the 1993-98 boom, the employment-population rate increased by 2.9 percentage points, or nearly 0.6 percentage points per year. ${ }^{23}$ If employment begins to increase in 2010 at the same rate as in that boom, the employment-population rate would not attain its pre-recession level of 63 per cent until 2017.

A deep, long recession creates long spells of joblessness that entails a huge cost to economic well-being for years. Studies of happiness show that unemployment reduces happiness more than almost anything else, short of the loss of a family member. ${ }^{24}$ Young

21 This is the BLS's U-6 measure that includes total unemployed, plus all marginally attached workers, plus total employed part time for economic reasons, as a percentage of the civilian labour force plus all marginally attached workers. Bureau of Labor Statistics, Economic News Release, table A-15 http://www.bls.gov/news.release/empsit.t15.htm.

22 See Bureau of Labor Statistics, International unemployment rates and employment indexes, seasonally adjusted, $2008-2010, \quad$ charts 1 and 2 (http://www.bls.gov/fls/intl_unemployment_rates_monthly.pdf ). Some countries, such as Germany and Sweden in Europe and the Republic of Korea in Asia, have "hidden" their joblessness by paying firms to keep workers on board (Freeman, 2010a).

23 See Bureau of Labor Statistics, Labor Force Statistics for the Current Population Survey, http://data.bls.gov/PDQ/servlet/SurveyOutputServlet? data_tool=latest_numbers\&series_id=LNS14000000 (change output options to "from 1993 to 1998" and click "go") (accessed 26 Feb. 2010).

24 Winkelman and Winkelman (1998) found that in Germany unemployed men were 38 per cent less likely to have high life satisfaction than employed men. Clark (2003) found that unemployed men in the United Kingdom were 69 per cent less likely to have a high quality of life score. 
people seeking first jobs and experienced workers who lose jobs in a weak job market suffer economic losses that last throughout their lives (Nakamura, 2009; von Wachter and Bender, 2006). The effects of job loss on health are more equivocal. Ruhm (2000) found that health improves in a recession. But, looking at high-seniority men who lost their jobs in the 1970s and 1980s, Sullivan and von Wachter (2009) estimate that their annual mortality increased by 10 to 15 per cent, which implies a loss in life expectancy of $12-18$ months. Longitudinal analysis by the OECD $(2008$, pp. 205, 209) of the mental health of individual workers in five countries shows that mental health suffers from loss of employment, and improves when the unemployed obtain full-time regular jobs.

Recessions can also increase inequality of earnings and wealth. In the United States, between 2007 and 2009, the usual hourly earnings increased more at the top decile than at the median, which in turn increased more than at the bottom decile. ${ }^{25}$ Earnings increased more for persons with graduate or professional degrees than for college graduates, whose earnings in turn increased more than for high-school graduates or those without college education. Earnings increased more for older than for younger workers, and so on. ${ }^{26}$ Median household income fell by 3.6 per cent in real terms between 2007 and 2008, while the rate of poverty rose from 12.5 per cent to 13.2 per cent (DeNavas-Walt, Proctor and Smith, 2008, pp. 6 and 14). Since the recession began in late 2008 , poverty and household income figures will almost certainly show greater losses throughout 2010. Wolff (2009) estimates that the mean wealth

Blanchflower and Oswald (2004) find that unemployment is associated with 23 per cent lower life satisfaction in the US General Social Survey. Strong in cross-section and found in longitudinal analyses as well, with analysis of timing of adaption: largest loss of subjective well-being is right after job loss (Lucas et al., 2004).

25 See Bureau of Labor Statistics, Usual Weekly Earnings of Wage and Salary Workers: Third Quarter 2007 (Oct. 18, 2007), http://www.bls.gov/schedule/archives/wkyeng_nr.htm\#current (click on "Third Quarter" for years 2007, 2008, and 2009 to compare).

26 See Bureau of Labor Statistics, Usual Weekly Earnings of Wage and Salary Workers: Third Quarter 2007 (Oct. 18, 2007), http://www.bls.gov/schedule/archives/wkyeng_nr.htm\#current (click on “Third Quarter" for years 2007. 2008, and 2009 to compare). 
fell less than median wealth between 2007 and 2009, which implies that inequality in wealth grew. ${ }^{27}$ The reason for increase in wealth inequality is that the government bailout of banks and stimulus helped raise share prices, which restored some of the wealth of persons with considerable equity, whereas the price of houses (the main wealth of most families) had not recovered by mid-2010. By contrast, inequality in income and wealth fell during the Great Depression, when the fall in asset values affected only the tiny "upper crust" of society holding investments in the stock market (Kuznets and Jenks, 1953, p. 11; Mendershausen, 1946, p. 35; Piketty and Saez, 2003; Kopczuk and Saez, 2004). ${ }^{28}$

\section{Long-term effects}

Earlier finance-induced recessions occurring since the end of the Second World War provide some insight into how the crisis might affect workers over the long run. The housing bubble and banking collapse in Sweden in the early 1990s raised unemployment from 1.8 per cent in 1990 to 9.6 per cent in 1994. In the ensuing recovery, unemployment bottomed out at 5 per cent in 2001. In 2007, 16 years after the crisis but before the 2008-09 recession, the rate of unemployment was 6.2 per cent - more than three times as high as in 1990. In 1997, the Asian financial crisis struck the Republic of Korea. The IMF and the United States insisted that it raise interest rates and undertake "Washington-Consensus style" reforms to receive the financial assistance it needed to deal with runs on its currency. Unemployment rose to around 8 per cent, real wages declined, and unions battled management and government in a futile effort to preserve job security for workers in large firms. Growth and employment recovered quickly, but the new jobs were primarily in "non-regular" positions with limited benefits and

27 “[M]ean wealth (in 2007 dollars) fell by 17.3 per cent between 2007 and 2009 (to $\$ 443,600$ ), median wealth plunged by an astounding 36.1 per cent (to $\$ 65,400$, about the same level as in 1992!" (Wolff, 2009, p. 3).

28 Since a small proportion of the population holds a disproportionate share of stocks and other fixed assets, whose prices fall in recessions, cyclic downturns often lower wealth inequality, as did the Depression. 
low wages. Inequality in the Republic of Korea went from moderate levels to the second highest among advanced OECD countries, just behind the United States. The recession in Argentina that followed the collapse of the peso in January 2002 raised already high rates of unemployment, lowered real wages and increased poverty (Saxton, 2003). The adverse effects of unemployment may last even longer because of intergenerational transmission. Lindo (2009, p. 1) reports that "husbands' job losses have significant negative effects on infant health. They reduce birth weights by approximately 4 per cent with the impact concentrated on the lower half of the birth weight distribution." Since low-birth children fare worse later in life, the implication is that these costs will persist into the distant future.

Finally, there are the costs to society of adjusting to the fiscal deficits and increased debt-to-GDP ratios associated with a huge recession. In the United States where state governments are constitutionally required to balance their budgets, spending on education and other public goods and teachers' employment have fallen in many places and are likely to drop more, once the stimulus funding ends (Lewin and Dillon, 2010). Throughout the world, governments will have to devote a larger budget share to paying interest on increased national debts in an effort to prevent a second Great Depression. Reinhart and Rogoff (2010) estimate that increased debt could rise to levels that will depress future growth rates around the world. When the debt/GDP ratio rises above 90 per cent in the countries/time periods in their data set, median growth rates fall by 1 per cent in both advanced and emerging economies. When external debt in emerging economies reaches 60 per cent of GDP, annual growth declines by about 2 per cent, while at higher levels growth rates are cut roughly in half and inflation rises. This view contrasts sharply with the assertion that because several large banks have paid back their TARP moneys with interest, then the bailout of banks has cost the United States little: the cost is in the increased debt to GDP ratio, unemployment, and lost production.

In sum, finance sent the global economy into a recession that has caused huge harm to the real economy, notably to working people in the advanced countries. Given this, it is 
incumbent on legislators and on governments concerned about the well-being of ordinary citizens to seek to reduce the likelihood and amplitude of such disasters in future at their place of incidence, namely, in financial markets.

Why has finance been so irresponsibly destructive?

Observers and analysts have sought to explain the behaviour that produced the financial implosion in a variety of ways.

Some attribute the excessive risk-taking and socially deleterious actions of financiers to the advent of the Gordon Gekko morality that extolled greed and profits above all else - as if financial markets were less concerned about money-making in earlier years. ${ }^{29}$ Others root the crisis in part in hormones (excessive testosterone among floor-traders and decisionmakers) mindful of the "animal spirits" that Keynes (1936) viewed as a major force in speculative booms. ${ }^{30}$ Studies that relate risk-taking to endocrines in the brain and measure which parts of the brain "light up" when people take financial risks provide a scientific underpinning for this hypothesis. ${ }^{31}$ In 2008, Alan Greenspan opined that Wall Street collapsed partly because risk modellers limited their data analysis to periods when the market was doing

29 John McCain spoke of "greed, corruption and excess" as "Wall Street treated the American economy like a casino" (Klein, 2008, p. 1). Charles Colson, the Watergate criminal who found new life as an evangelical prison ministry leader, declared that the problem was "greed unchecked by any moral restraint" (Colson, 2008). Greenspan referred to "an infectious greed [that] seemed to grip much of our business community" as if greed was not the putative motivating force for market capitalism (Binswanger, 2002). Playing the Clinton mantra, one religious leader explained "it's the morality, sinner" (Stoddard, 2008).

30 "Even apart from the instability due to speculation, there is the instability due to the characteristic of human nature that a large proportion of our positive activities depend on spontaneous optimism rather than on a mathematical expectation, whether moral or hedonistic or economic ... Most, probably, of our decisions to do something positive ... can only be taken as a result of animal spirits - of a spontaneous urge to action rather than inaction, and not as the outcome of a weighted average of quantitative benefits multiplied by quantitative probabilities" (Keynes, 1936, p. 161).

31 I review some of these studies in Freeman (2010b). 
well (Thibodeau, 2008). In 2010, some financial leaders told Congress they just did not understand what was going on and therefore could not be blamed, while others blamed rival firms and speculators who sought to sabotage them (Braithwaite, 2010).

Micro-economics suggests that rather than looking for explanations in incompetence, amorality or hormonal imbalance, we look cui bono at the monetary rewards that induced people to make the short-sighted, risky and self-interested decisions which contributed to the financial disaster. In the United States, in the 1970s, comedian Flip Wilson's character Geraldine used to explain her bad behaviour with the phrase "the devil made me do it". The hypothesis that seems most relevant in understanding behaviour in finance is that "the money makes them do it".

Certainly, the first thing that strikes anyone about finance is the huge amounts paid to those in important positions. Executive compensation in the United States allows top managers to earn massive amounts for meeting or seeming to meet performance criteria the managers set for themselves. In the 2000s, American executives were making roughly 300 times the earnings of normal workers, the bulk being paid in the form of stock options and bonuses. The latter was the preferred mode of executive compensation after the Clinton Administration's 1993 tax reform which denied a corporate tax deduction for pay in excess of US\$1 million..$^{32}$ The exceptional pay of management reflects three to four decades of rising income inequality that brought Gini coefficients and other measures of inequality to levels comparable with those existing before the Great Depression (Piketty and Saez, 2003). Much of the income gain in the United States in the 1980s-2000s went to the top 10 per cent, and much of the upper 10 per cent's income gain went to the top 1 per cent of that decile, and

32 With a 35 per cent corporate tax rate, it cost corporations 35 per cent more than before to pay their top executives above US\$1 million per year, so companies shifted CEO compensation toward options, on which recipients did not have to pay taxes until exercised, and which were not counted as an expense on corporate books (Domhoff, 2005). 
much of the gain in the upper 1 per cent went to the upper 0.1 per cent and so on (see Gordon and Dew-Baker, 2008).

In order to cash in on options or to make huge bonuses, management had to report financial statistics in ways that raised share prices. They could do this by improving the firm's production possibility frontier; by redistributing economic rents from workers or consumers to the firm; or by finding ways of reporting high profits and boosting share prices which would redistribute revenues from shareholders to management.

Until the implosion of Wall Street, many believed that finance made its money by creating better financial products. That presumably was the job both of the mathematical finance quants, who developed new models to assess risk and new financial instruments to spread risk more widely among those with a high risk-tolerance, and of the investment managers, who sought to deploy capital more productively. The discovery that so many assets were toxic and either erroneously valued or impossible to value in the crisis has discredited this belief.

The redistribution of rents seems to be the main mechanism behind high and rising incomes in finance. This is particularly striking in the credit card business, where some 75 per cent of the industry's consumer-fee income comes from overdraft and insufficient-funds charges, owing at least partly to consumer ignorance of the cost of those charges (Kim, 2009). Opposition to the Obama Administration's proposed consumer financial protection agency seems based on the fear that protection against fraudulent or misleading financial products will squeeze profits and pay. Redistribution based on exploiting consumer ignorance does not directly harm national output, but may cause economic problems by inducing consumers to take on greater debt, and misallocate human capital in the industry by inducing managements to find ways of tricking consumers, rather than improving products or cutting costs.

Gaming the compensation system by misreporting financial returns affects both the distribution of incomes and economic efficiency. Since stock options are more valuable when 
the variance of share prices is high, one way of increasing the value of options is to make riskier decisions than may be in the interest of the firm. Sanders and Hambrick (2007) found that firms where the CEO's compensation was loaded with options showed greater variation in performance than other firms. If the gains to the winners were to exceed the losses to the losers, this would raise total output and would probably be in the interest of the broader economy. But Sanders and Hambrick found that riskier behaviour produced more large losses than large gains (ibid.).

In a simple, maze-solving laboratory experiment involving modest stakes for the participants who solved more mazes, Alexander Gelber and I found that greater incentives to come higher in a tournament induced participants to misreport the number of mazes they had solved (Freeman and Gelber, 2010). The massive sums involved in finance provide greater incentives to misrepresent performance, and a growing literature in economics, management and accounting finds that financial misreporting is more likely when executives benefit through stock options and equity from the misreporting. These studies rely on two data sources: a 2002 Government Accountability Office (GAO) report on financial restatements and the quarterly SEC reports of Accounting and Auditing Enforcement Releases (AAER). Because both data sets have relatively few observations, however, causal interpretation of the links between executive pay and misreporting depends on econometric specification. Summarizing the literature, Armstrong, Jagolinzer, and Larcker (2010) report that eight out of ten studies found that improper reporting is associated with "the strength of inducements", but that the result does not hold up in the AAER data when they estimate presumptively better statistical models based on propensity score models that match firms that misreported their finances with observationally equivalent firms that did not. Perhaps, as in the Freeman-Gelber experiment, only small rewards are necessary to generate misreporting. But it is difficult to explain the behaviour of managements illegally "working the books" (Enron, AIG, Global Crossing, etc.) in any other terms than money-making. Similarly, the practice of backdating 
stock options (which may or may not be legal) has no other explanation than money-making (Lie, 2005; Heron and Lie, 2009; Heron and Lie, 2007). Thus the issue is not so much whether incentives induce misreporting or other forms of rent-seeking, but whether increased incentives induce more such behaviour in ways that show up in the limited data available.

The implication of this analysis is antipodal to the usual supply-side claim that huge inequalities are needed to motivate those at the top to make the best decisions. It suggests instead that smaller rewards at the top may be needed to reduce the amount of "bogus" money-making and unscrupulous risk-taking that underlay the Wall Street implosion - at least at the levels of earnings that characterize the United States economy (Andrews and Bajaj, 2009).

Finally, while economics stresses conscious responses to incentives, incentives can affect behaviour unconsciously too. Scientists whose research is supported by drug firms report more favourably on drugs than scientists whose research is funded otherwise. ${ }^{33}$ Some recipients of drug company support may consciously distort their results, but most presumably come up with the "right" answers through unconscious decisions made during their experiments. It is for this reason that the gold standard in clinical trials is double-blind studies in which neither the researcher nor the subjects know who is in the control or in the treatment group, and for which the assays are done by an independent laboratory that is unaware of which specimens come from which group. I surmise that some of the amoral, "greedy" decisions made by the bankers and financiers reflected unconscious responses to incentives, as well as purposive policies to enrich themselves at the expense of shareholders, consumers, or workers.

33 Finucane and Boult (2004) reported that none of the 30 industry-supported studies that they examined gave a result unfavourable to the drug studied, whereas one-third of studies that were not industry-supported had unfavourable findings; Lexchin et al. (2003) reported that systematic bias favours products made by the company funding the research; Yank, Rennie and Bero (2007) reported that meta-analyses show that research with financial ties to one drug company is not associated with favourable results but with favourable conclusions. 
Where were the regulators?

Another set of explanations for the malfunctioning of finance focuses on the failure of governmental and international regulators. The hypothesis is that regulatory bodies did not set appropriate capital and reporting requirements; failed to monitor "shadow banking" activities that raised leverage (the result of the decision by the Clinton Administration and the Federal Reserve to trust derivatives to market forces); and failed to respond to information suggesting that something was seriously awry in finance.

There is evidence on the failure to respond to information that relates directly to the collapse of subprime mortgages which sparked the Wall Street crisis. Long before the collapse of subprime mortgages, the Federal Bureau of Investigation had noted a peculiar trend in the "suspicious activity reports" (SARs) that the United States Department of the Treasury's Financial Crimes Enforcement Network (FinCen) gathers from banks and other money service businesses. ${ }^{34}$ The number of SARs reported to FinCen associated with mortgage fraud grew exponentially between 1997 and 2006-07. In 2004, the FBI was sufficiently alarmed to announce publicly that "Mortgage fraud (was) becoming an "epidemic" " and risked recreating the savings and loan crisis of the $1980 \mathrm{~s} .{ }^{35}$ Neither the Federal Reserve nor the Bush Administration reacted to this news. Chairman Greenspan who had famously claimed to be unable to tell a healthy boom from a bubble in housing probably paid little attention to such "non-financial" data in assessing the economy. What could the FBI know that the market did not already know? Perhaps the Administration viewed FBI investigations of criminal activity as irrelevant for economic activity writ large. Had the

34 The form (downloadable from http://www.irs.gov/pub/irs-pdf/ffc109.pdf [accessed 18 May 2010]) asks specifically about money laundering, structuring and terrorist financing but encourages reporting banks to note other forms of suspicious transaction.

35 See http://www.usatoday.com/money/perfi/housing/2004-09-17-mortgage-fraud_x.htm [accessed 18 May 2010]; and http://www.facebook.com/topic.php?uid=2255675352\&topic=7398 [accessed 18 May 2010]. 
government authorities taken the FBI evidence-based warnings as seriously as they surely take evidence-based warnings of terrorism, they might have increased the number of FBI investigators examining the SARs, and possibly reduced the housing bubble and curtailed the spread of toxic assets.

However, regulatory and political failure to act should not be viewed as some factor exogenous to the crisis. Here, too, incentives presumably operate. Finance donates money to politicians. Regulators often end up working in the sector they used to regulate, or lobbying on behalf of that sector. The movement of people and money between Wall Street and Washington almost certainly reduced regulatory zeal, consistent with economic models of regulatory capture. Examining the link between finance and regulation, former IMF chief economist Simon Johnson asserted that "elite business interests - financiers, in ... the United States - played a central role in creating the crisis ... [and] are now using their influence to prevent ... reforms. One channel of influence ... [is] the flow of individuals between Wall Street and Washington" (Johnson, 2009, pp. 4 and 6). Testifying before Congress, former IMF chief economist Raghuram Rajan said that the " single biggest distortion ... is when a number of private institutions are deemed by political and regulatory authorities as too systemic to fail. ... The consequences [are].... system of crony capitalism. ... two sets of rules, one for the systemically important, and another for the rest of us" (Rajan, 2009, p. 1).

Indeed, once the banks recovered their profitability, they lobbied Congress to prevent financial-sector reforms that threatened to shrink their economic role and, presumably, their earnings as well. They contributed campaign funds to Congress members on the committees considering reform legislation, and deployed lobbyists extensively. Adam Smith warned long ago that "We rarely hear, it has been said, of the combinations of masters, though frequently of those of workers. But whoever imagines, upon this account, that masters rarely combine, is as ignorant of the world as of the subject" (1776, Book 1, chapter 8). 
Reform finance or suffer the consequences

Three lessons may be drawn from the implosion of the Wall Street model of capitalism.

The first is that "Financial markets can destroy economies whereas labour markets cannot." The implication is that over the past 20 years much of the debate on labour market reforms to improve economies has been misplaced. Analysts and policy-makers have focused on modest welfare-triangle inefficiencies due to regulations or to union activity (associated with a more egalitarian distribution of income), while ignoring the 800-pound financial gorilla (associated with a more unequal distribution of income). To avoid further economic disaster, decision-makers will have to find ways of shrinking the gorilla and turning it from master of the real economy into servant of the real economy.

The second lesson is that "High-powered incentives in finance are a fundamental cause of the excessive risk-taking, chicanery and financial fraud that can destroy financial markets". Because market behaviour responds to incentives, participants will invariably be prone to excessive risk-taking, chicanery and financial fraud. Letting Wall Street be Wall Street in the belief that the market will police itself in the face of huge financial incentives is a ticket to another crash. A new compensation system that rewards finance for contributing to the real economy and that penalizes financial misconduct and rent-seeking is a necessary part of any reform agenda.

The third and most depressing lesson is that "Reforming finance will be an uphill battle requiring the countervailing power of groups outside the sector in order to succeed." In the immediate aftermath of the collapse of Wall Street, many people anticipated that the banks and bankers whose survival depended on government bailouts would keep a low profile, as the United States and other countries sought ways of reforming their industry. After all, this had occurred in the bank reforms undertaken in the Great Depression. But this time, almost from the day they received their bailout moneys the banks have regained their mojo and battled to restore as much of the status quo ante as they can. 
The vast majority of the population who earn their livings in the real economy need a well-functioning finance sector that creates value, rather than one engaging in rent-seeking that destroys value. It would be criminal negligence to allow the financial system to continue to operate as it has in recent years. Reforms will not come easily but we must succeed, so we will succeed.

It's financialization!

International Labour Review

Copyright (C) The author 2010

Journal compilation (C) International Labour Organization 2010 
References

Anderson, Jenny; Creswell, Julie. 2007. “Top hedge fund managers earn over \$240 million”, i nNew York Times, 24 Apr. Available at: http://www.nytimes.com/2007/04/24/business/24hedge.html?fta=y\&pagewanted=all [accessed 14 May 2010].

Andrews, Edmund L.; Bajaj, Vikas. 2009. "US plans $\$ 500,000$ cap on executive pay in bailouts", inNew York Times, 4 Feb. Available at: http://www.nytimes.com/2009/02/04/business/04pay.html/ [accessed 18 May 2010].

Armstrong, Christopher; Jagolinzer, Alan D.; Larcker, David F. 2010. "Chief Executive Officer equity incentives and accounting irregularities", in Journal of Accounting Research, Vol.48, No. 2, pp. 225-271.

Baily, Martin Neil; Schwartz, Bernard L. (respectively Senior Fellow and Chair, The Brookings Institution). 2009. Testimony to the Senate Democratic Policy Committee: "Putting Americans back to work; Competing visions for job creation", 16 Dec. Available at: http://dpc.senate.gov/hearings/hearing52/baily.pdf [accessed 14 May 2010].

Bankers Almanac. 2010. "Top banks in the world by BankersAlmanac.com", as at 3 Mar. 2010 , available a t: http://www.bankersalmanac.com/addcon/infobank/bankrankings.aspx.

Binswanger, Harry. 2002. "Greenspan on 'infectious greed", in Capitalism Magazine, 30 Aug. Available at: http://www.capmag.com/article.asp?ID=1825 [accessed 17 May 2010].

Bivens, Josh. 2010. Budgeting for recovery: The need to increase the federal deficit to revive a weak economy. EPI Briefing Paper No. 253. Washington, DC, Economic Policy Institute. 6 Jan. Available at: http://epi.3cdn.net/1616707e0c784d8134_4nm6becsb.pdf [accessed 14 May 2010]. 
Blanchflower, David G.; Oswald, Andrew J. 2004. Money, sex and happiness: An empirical study. NBER Working Paper No. 10499. Cambridge, MA, National Bureau of Economic Research.

Braithwaite, Tom. 2010. "Bear Stearns chief blames banks failure on rumour and speculation", inFinancial Times, 6 May. Available at: http://www.ft.com/cms/s/0/2e11ad84-586e-11df-9921-00144feab49a.html? nclick_check=1 [accessed 17 May 2010].

Bureau of Labor Statistics. 2010. Regional and state employment and unemployment summary. 22 Jan. Available at: http://www.stats.bls.gov/news.release/laus.nr0.htm [accessed 14 May 2010].

Clark, Andrew E. 2003. "Unemployment as a social norm: Psychological evidence from panel data", in Journal of Labor Economics, Vol. 21, No. 2, pp. 323-351.

Council of Economic Advisors, Economic Report of the President: 2010 Report Spreadsheet Tables (http://www.gpoaccess.gov/eop/tables10.html)

Colson, Chuck. 2008. “Tipsy on Wall Street: A President's candid comment”, in Crosswalk, 29 July. Available at: http://www.crosswalk.com/news/commentary/11579703/ [accessed 16 May 2010].

Craig, Suzanne. 2008. "The week-end that Wall Street died", in Wall Street Journal, 29 Dec. Available at http: http://online.wsj.com/article/SB123051066413538349.html [accessed 14 May 2010].

DeNavas-Walt, Carmen; Proctor, Bernadette D.; Smith, Jessica C., US Census Bureau. 2009. Income poverty and health insurance coverage in the United States: 2008. Washington, DC, U.S. Government Printing Office. Available at: http://www.census.gov/prod/2009pubs/p60-236.pdf [accessed 20 May 2010].

Domhoff, G. William. 2005 (updated Apr. 2010). "Wealth, income, and power", Sep., available at: http://sociology.ucsc.edu/whorulesamerica/power/wealth.html [accessed 17 May 2010]. 
Finucane, Thomas E.; Boult, Chad E. 2004. "Association of funding and findings of pharmaceutical research at a meeting of a medical professional society", in American Journal of Medecine, Vol. 117, No. 11, pp. 842-845.

Freeman, Richard B. 2010a. EU institutional model vs. US/Anglo model responses to the bankers' recession. Contribution to the Panel Discussion on "Europe's role and position in the current economic crisis," at the Annual Meeting of the American Economic Association, held in Atlanta, GA, 5 Jan.

-. 2010b. "Reforming the United States' economic model after the failure of unfettered financial capitalism" (The Kenneth M. Piper Lecture), in Chicago Kent Law Review, Vol. 85, No. 2, pp. 685-720.

—. 2007. "How well do the clothes fit? Priors and evidence in the debate over flexibility and labour market performance", in Barry Eichengreen, Dieter Steifel and Michael Landesmann (eds): The European economy in an American mirror, Vol. 1: Growth, competitiveness and employment, chapter 9. London, Routledge.

—. 2005. "Labour market institutions without blinders: The debate over flexibility and labour market performance", in International Economic Journal, Vol. 19, No. 2, pp. 129145 .

-; Gelber, Alexander M. 2010. "Prize structure and information in tournaments: Experimental evidence", in American Economic Journal: Applied economics, Vol. 2, No. 1, pp. 149-164.

Gordon, Robert J.; Dew-Baker, Ian. 2008. Controversies about the rise of American inequality: A survey. NBER Working Paper No. 13982. Cambridge, MA, National Bureau of Economic Research. Available at: http://www.nber.org/papers/w13982 [accessed 17 May 2010].

Harrison, Edward. 2009. "Obama: Debt could cause a double-dip recession", in Naked Capitalism, 18 Dec. Available at: http://www.nakedcapitalism.com/2009/11/obamadebt-could-cause-a-double-dip-recession.html [accessed 14 May 2010]. 
Heron, Randall A.; Lie, Erik. 2009. "What fraction of stock option grants to top executives have been backdated or manipulated?", in Management Science, Vol. 55, No. 4, pp. $513-525$.

—; - 2007. "Does backdating explain the stock price pattern around executive stock option grants?”, in Journal of Financial Economics, Vol. 83, No. 2, pp. 271-295.

IILS (International Institute for Labour Studies). 2009. World of Work Report 2009: The global jobs crisis and beyond. Geneva.

ILO. 2009. Report of the Committee of the Whole on Crisis Responses. International Labour Conference, $98 \mathrm{th}$ Session, 2009 . Geneva. Available at: http://www.ilo.org/global/What_we_do/Officialmeetings/ilc/ILCSessions/98thSession/ pr/lang--en/docName--WCMS_108440/index.htm [accessed 14 May 2010].

IMF. 2009. World Economic Outlook. Washington, DC.

Johnson, Simon. 2005. "The quiet coup", in Atlantic Monthly, available at: http://www.theatlantic.com/magazine/archive/2009/05/the-quiet-coup/7364/ [accessed 18.05.2010].

Keynes, John Maynard. 1936. The general theory of economics. [Reprinted as The general theory of employment, interest and money. New York, NY, Palgrave Macmillan, 2007.]

Kim, Jane J. 2009. "Bank suspends overdraft fee increase", in Wall Street Journal, 14 Apr. Available at: http://online.wsj.com/articles/SB123967277269015845.html [accessed 17 May 2010].

Klein, Rick. 2008. "McCain blames greed for Wall St. mess; Obama blames GOP”, in $A B C$ News, 16 Sep., available at: http://abcnews.go.com/Politics/5050/story? $\mathrm{id}=5812268 \&$ page $=1$ [accessed 16 May 2010]. 
Kopczuk, Wojciech; Saez, Emmanuel. 2004. Top wealth shares in the United States, 19162000: Evidence from estate tax returns. NBER Working Paper No. 10399. Cambridge, MA, National Bureau of Economic Research. Available at: http://www.nber.org/papers/w10399 [accessed 16 May 2010].

Kose, M. Ayhan; Prasad, Eswar; Rogoff, Kenneth; Wei, Shang-Jin. 2006. Financial globalization : A reappraisal. IMF Working Paper No. 06/189. Washington, DC, International Monetary Fund.

Kuznets, Simon; Jenks, Elizabeth. 1953. "Average levels of income shares, 1919-1938”, in Simon Kuznets (ed.) with Elizabeth Jenks: Shares of upper income groups in income and savings. Cambridge, MA, National Bureau of Economic Research, pp. 1-31.

Laeven, Luc; Valencia, Fabian. 2008. Systemic banking crises: A new database. IMF Working Paper No. 08/224. Washington, DC, International Monetary Fund. Available at: http://www.imf.org/external/pubs/ft/wp/2008/wp08224.pdf [accessed 14 May 2010].

Lewin, Tamar; Dillon, Sam. 2010. "Districts warn of deeper teacher cuts", in New York Times, 20 Apr. Available at: http://www.nytimes.com/2010/04/21/education/21teachers.html [accessed 16 May 2010].

Lexchin, Joel; Baro, Lisa A.; Djulbegovic, Benjamin; Clark, Otavio. 2003. "Pharmaceutical industry sponsorship and research outcome and quality: Systematic review", in British Medical Journal, Vol. 326, pp. 1167-1170.

Lie, Erik. 2005. "On the timing of CEO stock option awards", in Management Science, Vol. 51, No. 5, pp. 802-812.

Lindo, Jason. 2010. Parental job loss and infant health. Available at: http://www.nber.org/confer/2010/CHEDs10/Lindo.pdf [accessed 16 May 20109]

Lucas, Richard; Clark, Andrew; Georgellis, Yannis; Diener, Ed. 2004. "Unemployment alters the set-point for life satisfaction", in Psychological Science, Vol. 15, No 1, pp. 8-13. 
Mendershausen, Horst. 1946. Changes in income distribution during the Great Depression. New York, NY, National Bureau of Economic Research.

Nakamura, Emi. 2008. "Layoffs and lemons over the business cycle", in Economics Letters, Vol. 99, No. 1, pp. 55-58.

OECD. 2009. Employmen Outlook. Paris.

—. 2008. Employment Outlook. Paris.

Ohanian, Lee E. 2009. "The $\$ 787$ billion mistake", in Forbes, 10 June. Available at: http://www.forbes.com/2009/06/09/american-recovery-reinvestment-act-rooseveltopinions-contributors-depression.html [accessed 14 May 2010].

Paulden, Pierre; Detrixhe, John. 2010. "Goldman Sachs helps YRC avert bankruptcy following Hoffa's plea", on Bloomberg TV, 1 Jan. Available at: http://www.bloomberg.com/apps/news?pid=20601087\&sid=akW2fq12ZKOA [accessed 14 May 2010].

Piketty, Thomas; Saez, Emmanuel. 2003. "Income inequality in the United States, 19131918", in Quarterly Journal of Economics, Vol. 118, No. 1, pp. 1-39.

Prasad, Eswar S.; Rajan, Raghuram G.; Subramanian, Arvind. 2007. Foreign capital and economic growth. NBER Working Paper No. 13619. Cambridge, MA, National Bureau of Economic Research.

Rajan, Raghuram G. 2009. Testimony before the Senate Banking Committee Hearings, 6 May. Available at: http://www.chicagobooth.edu/news/TooSystemicToFail.pdf [ accessed 18 May 2010].

Reinhart, Carmen; Rogoff, Kenneth. 2010. Growth in a time of debt. NBER Working Paper 15639. Cambridge, MA, National Bureau of Economic Research, Jan.

—; - 2009. This time is different: Eight centuries of financial folly. Princeton, NJ, Princeton University Press. 
Ruhm, Christopher R. 2000. “Are recessions good for your health?”, in Quarterly Journal of Economics, Vol. 115, No. 2, pp. 617-650.

Sanders, Wm Gerard; Hambrick, Donald C. 2007. "Swinging for the fences: The effects of CEO stock options on company risk taking and performance", in Academy of Management Journal, Vol. 50, No. 5, pp. 1055-1076.

Saxton, Jim. 2003. “Argentina's economic crisis: Causes and cures”, Testimony before the Joint Economic Committee of the United States Congress, June. Available at: http://www.house.gov/jec/imf/06-13-03.pdf [accessed 17 May 2010].

Shiller, Robert J. 2003. The new financial order: Risk in the 21st century. Princeton, NJ, Princeton University Press.

Smith, Adam. 1776. An inquiry into the nature and causes of the wealth of nations.

Stoddard, Ed. 2008. "Evangelicals see moral decline in Wall St. woes", 1 Oct. Available from Reuters at: http://www.reuters.com/article/idUSTRE4905RF20081001 [accessed 17 May 2010].

Sullivan, Daniel; von Wachter, Till. 2009. "Job displacement and mortality: An analysis using administrative data", in Quarterly Journal of Economics, Vol. 124, No. 3, pp. 12651306.

Thibodeau, Patrick. 2008. "Greenspan: Bad data hurt Wall Street computer models", in New York Times. 23 Oct. Available at: http://www.nytimes.com/external/idg/2008/10/23/23idg-Greenspan-Bad.html [accessed 17 May 2010].

Von Wachter, Till; Bender, Stefan. 2004. In the right place at the wrong time: The role of firms and luck in young workers' careers. IZA Discussion Paper No. 1348. Bonn, Institute for the Study of Labour. 
Walker, Marcus. 2009. "Record GDP drop sharpens pain across Euro-zone", in Wall Street Journal, 16 May, at A5.

Whitehouse, Mark. 2009. “The outlook: Economic crisis ebbs, systemic risks don't”, in Wall Street Journal, 7 Dec.

Winkelman, Liliana; Winkelman, Rainer. 1998. "Why are the unemployed so unhappy? Evidence from panel data", in Economica, Vol. 65, pp. 1-15.

Wolff, Edward N. 2009. "The squeeze before the storm", in Pathways, Fall, pp. 3-7.

Yank, Veronica; Rennie, Drummond; Bero, Lisa A. 2007. "Financial ties and concordance between results and conclusions in meta-analyses: Retrospective cohort study", in British Medical Journal, Vol. 225, pp. 1202-1205.

Zuckerman, Mortimer B. 2008. "We deserve a better bailout", in US News and World Report, Available at: http://www.usnews.com/opinion/mzuckerman/articles/2008/10/03/wedeserve-a-better-bailout.html [accessed 14 May 2010]. 